\title{
FAKTOR-FAKTOR YANG MEMPENGARUHI NILAI PERUSAHAAN
}

\author{
Henryanto Wijaya \\ Universitas Tarumanagara \\ henryantow@fe.untar.ac.id \\ Delvinia Regina Tania \\ Universitas Tarumanagara \\ delviniakyu@gmail.com \\ Hadi Cahyadi \\ Universitas Tarumanagara \\ hadic@fe.untar.ac.id
}

\begin{abstract}
:
The purpose of this study is to re-evaluate the effect of profitability and leverage on firm value and to determine the role of Corporate Social Responsibility (CSR) as a moderating variable in manufacturing companies listed on the Indonesia Stock Exchange (BEI) 2016-2018. This study took 50 samples of companies using purposive sampling method. This study was also conducted with the help of E-Views 9.0 software to process data. The results of this study indicate that profitability has a negative and insignificant effect on firm value, Leverage has a negative and insignificant effect on firm value, Corporate Social Responsibility (CSR) has a negative and insignificant effect on firm value, Corporate Social Responsibility (CSR) weakens the effect of profitability on firm value, and also weaken the effect of leverage on firm value.
\end{abstract}

Keywords: Firm Value, Profitability, Leverage, CSR

\begin{abstract}
ABSTRAK:
Tujuan dari penelitian ini adalah untuk mengevaluasi kembali pengaruh dari profitabilitas dan leverage terhadap nilai perusahaan serta untuk mengetahui peranan dari Corporate Social Responsibility (CSR) sebagai variabel pemoderasi pada perusahaan Manufaktur yang tedaftar di Bursa Efek Indonesia (BEI) tahun 2016-2018. Penelitian ini mengambil 50 sampel perusahaan dengan memanfaatkan metode Purposive Sampling. Penelitian ini juga dilakukan dengan bantuan software E-Views 9.0 untuk memproses data. Hasil dari penelitian ini menunjukkan bahwa profitabilitas berpengaruh negatif dan tidak signifikan terhadap nilai perusahaan, Leverage berpengaruh negatif dan tidak signifikan terhadap nilai perusahaan, Corporate Social Responsibility (CSR) berpengaruh negatif dan tidak signifikan terhadap nilai perusahaan, Corporate Social Responsibility (CSR) memperlemah pengaruh profitabilitas terhadap nilai perusahaan, dan juga memperlemah pengaruh leverage terhadap nilai perusahaan.
\end{abstract}

Kata kunci : Nilai Perusahaan, Profitabilitas, Leverage, CSR 


\section{PENDAHULUAN}

Nilai perusahaan merupakan pandangan yang diberikan oleh investor terhadap tingkat keberhasilan dari sebuahperusahaan yang sering dihubungkan dengan harga saham sehingga dapat meningkatkan kualitas dan kepercayaan dari para pemegang saham. Harga saham merupakan sumber informasi yang penting bagi para pemegang saham, semakin tinggi harga saham yang dimiliki oleh perusahaan maka semakin tinggi pula kemakmuran dan kesejahteraan para pemegang sahamnya. Perusahaan dengan harga saham yang tinggi membuat nilai perusahaan menjadi tinggi dan meningkatkan kepercayaan dari pangsa pasar terhadap kinerja perusahaan. Nilai profitabilitas menunjukkan tingkat laba dan efisiensi perusahaan dalam kondisi baik serta menunjukkan bahwa nilai perusahaan berada dalam tingkat yang tinggi sehingga dapat menarik minat investor untuk menanamkan modalnya pada perusahaan.

Leverage menunjukkan tingkatan dari kapabilitas perusahan demi tujuan untuk menyelesaikan seluruh beban finansialnya. Disebutkan bahwa apabila tingkat dari rasio leverage suatu perusahaan tinggi, artinya perusahaan akan menahan laba operasional perusahaannya agar dapat digunakan untuk melunasi utang perusahaan. Dalam menentukan leverage perusahaan harus mempertimbangkan dengan lebih baik dahulu karena dapat menimbulkan beban dan juga resiko bagi perusahaan apabila perusahaan tersebut dalam kondisi yang tidak baik karena penggunaan utang ini akan berdampak pada nilai perusahaan.

Corporate Social Responsibility (CSR) merupakan sebuah gagasan yang fokus pada tanggung jawab suatu perusahaan dalam keserasian antara kepedulian pada dimensi dimensi seperti ekonomi, sosial, dan juga lingkungan hidup. Praktik dari program CSR disebut dapat mengurangi suatu potensi bila perusahaan tidak disambut di dalam lingkungan yang akan berbenturan dengan aktivitas operasional sebuah perusahaan. Jika banyak program CSR yang diterapkan oleh perusahaan, dengan itu nilai perusahaan akan ikut berkembang akibat dari pasar yang memberikan suatu reaksi yang baik pada perusahaan yang turut menerapkan CSR demi tercapainya suatu pertumbuhan dari harga saham perusahan. 


\section{TELAAH LITERATUR}

Teori Keagenan atau teori agensi merupakan suatu teori yang menjabarkan tentang keterkaitan dari pemilik suatu perusahaan (pemegang saham atau stakeholders) dan pihak tata laksana atau pihak manajemennya. Konsep Agency Theory menurut pendapat (Scott, 2015) adalah ikatan atau komitmen yang terjadi pada prinsipal dan juga pihak agennya. Prinsipal merupakan pihak yang berwenang memberikan kewajiban pada agen untuk melaksanakan tugas demi kebutuhan prinsipal, sedangkan agen merupakan pihak pelaksana kebutuhan dari prinsipal itu sendiri.

Teori Legitimasi merupakan teori yang mengatakan demi untuk mendapatkan rasa percaya dan keyakinan dari kelompok masyarakyat umum yang didasarkan pada kegiatan yang dijalankan oleh perusahaan, maka perusahaan wajib menerapkan kegiatan yang berkeyakinan pada norma serta aturan yang berlangsung pada bagian dalam lingkup sekitar perusahaan. Demi tetap mendapatkan legalitas dari masyarakat, maka perusahaan patut mendiskusikan aktivitas lingkungan dengan melakukan pengungkapan lingkungan social (Berthelot \& Robert, 2011).

Teori Stakeholder menekankan kesadaran perusahaan untuk mempertimbangkan kebutuhan, kepentingan, serta pengaruh dari pihakyang terkena dampak kebijakan dan operasi perusahaan. Perusahaan yang sukses adalah perusahaan yang dapat memuaskan permintaan berbagai stakeholder (Deegan, 2014).

Teori Kontrak Sosial ada karena hal itu disebabkan akibat terdapat suatu hubungan dalam aktivitas kemasyarakatan, demi terciptanya harmoni, keseragaman, dan kesetimbangan terhitung pula dalam suatu lingkungan. Relasi perusahaan bersama komunitas masyarakat akan senantiasa berupaya menaati dan melaksanakan adat serta tatanan hukum yang terdapat pada lingkup masyarakat, sampai aktivitas dari perusahaan dapat diakui oleh masyarakat (Deegan, 2014). 
Profitabilitas digunakan untuk dapat menilai kemampuan yang dimiliki perusahaan dalam usahanya mencari profit. Semua perusahaan berusaha untuk meningkatkan profitabilitas perusahaannya karena dengan mendapatkan keuntungan besar, maka akan berpengaruh pada tingkat kemampuan perusahaan untuk membagikan dividen yang akan berdampak pula pada nilai perusahaan yang semakin meningkat (Kasmir, 2014).

(Fahmi, 2015) mengatakan bahwa fungsi dari leverage yaitu untuk menafsirkan setinggi apakah aktivitas perusahaan didanai menggunakan utang atau pinjaman. Pemanfaatan pinjaman yang terlampau banyak akan memberikan dampak berbahaya pada perusahaan dikarenakan perusahaan akan terperangkap dalam extreme leverage (pinjaman berlebihan) yakni perusahaan terbelit pada tahap pinjaman yang tidak ada habisnya dan berat untuk membebaskan diri dari kewajiban menyelesaikan utang tersebut.

Johnson dan Johnson dalam (Hadi, 2014), membahas tentang tanggung jawab sosial perusahaan di mana organisasi atau perusahaan diwajibkan dapat menyelenggarakan tata proses kegiatan usahanya dengan cara mewujudkan suatu inovasi yang dapat beradaptasi secara nyata dan tegas terhadap rakyat umum dan lingkungan hidup. Semakin tingginya tingkat CSR tersebut maka akan membangun reputasi perusahaan menjadi lebih baik. Perusahaan ditekankan bahwa tidak boleh hanya mementingkan profit keuangannya sendiri serta keseluruhan bagian yang ada, namun juga harus diaplikasikan kepada masyarakat, terutama lingkup sekitar di mana aktivitas perusahaan dilaksanakan.

Berdasarkan uraian di atas, berikut ini disajikan kerangka pemikiran dan hipotesis yang digunakan dalam penelitian ini:

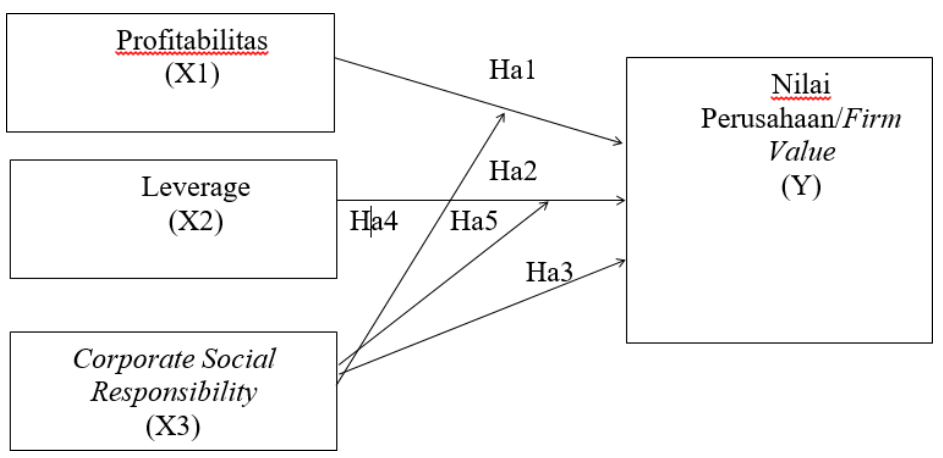

Gambar 1 Kerangka Pemikiran 
$\mathrm{H}_{\mathrm{al}}$ : Profitabilitas berpengaruh positif dan signifikan pada nilai perusahaan.

$\mathrm{H}_{\mathrm{a} 2}$ : Leverage berpengaruh positif dan signifikan pada nilai perusahaan.

$\mathrm{H}_{\mathrm{a} 3} \quad$ : Corporate Social Responsibility

(CSR) berpengaruh positif dan signifkan pada nilai perusahaan

\section{METODOLOGI PENELITIAN}

Observasi ini dilakukan dengan menggunakan sampel perusahaan manufaktur yang terdaftar di Bursa Efek Indonesia pada periode 2016-2018. Teknik pemilihan sampel yang digunakan adalah Purposive Sampling. Observasi ini dilakukan dengan tujuan untuk menguji efek dari profitabilitas serta leverage pada pengaruhnya terhadap nilai perusahaan serta penggunaan Corporate Social Responsibility sebagai variabel moderasi. Terdapat 50 perusahaan manufaktur yang sudah memenuhi kriteria sampel sehingga ada 150 sampel yang digunakan di dalam penelitian ini. Kriteria-kriteria sampel tersebut yaitu seperti: (1.) Perusahaan manufaktur yang terdaftar di Bursa Efek Indonesia selama periode 2016-2018, (2.) Perusahaan manufaktur yang melakukan Initial Public Offering (IPO), Perusahaan yang melakukan delisting, dan Perusahaan

\author{
$\mathrm{H}_{\mathrm{a} 4}$ : Corporate Social Responsibility \\ mampu memoderasi pengaruh \\ profitabilitas pada nilai perusahaan \\ $\mathrm{H}_{\mathrm{a} 5} \quad$ : Corporate Social Responsibility \\ mampu memoderasi pengaruh \\ leverage pada nilai perusahaan.
}

yang melakukan relisting, (3.) Perusahaan manufaktur yang tidak menyajikan laporan keuangan lengkap per 31 Desember selama periode 2016-2018, (4.) Perusahaan manufaktur yang mengalami kerugian selama periode 2016-2018, (5.) Perusahaan manufaktur yang tidak menggunakan mata uang rupiah sebagai mata uang transaksi selama periode 2016-2018. Obyek penelitian yang digunakan adalah laporan keuangan perusahaan yang diperoleh dari www.idx.co.id atau situs resmi BEI.

Variabel terikat yang ada pada observasi ini adalah Firm Value (nilai perusahaan) yang dihitung dengan formula TOBIN'S $Q$ dan variabel bebas yang ada dalam observasi ini adalah Profitability yang dihitung dengan formula Return on Assets (ROA) serta Leverage yang dihitung dengan formula Debt to Equity Ratio (DER). 
Sedangkan variabel moderasi yang Nilai Perusahaan (Firm Value) diukur digunakan adalah Corporate Social dengan TOBIN'S $Q$ yang dihitung dengan Responsibility (CSR). Pada penelitian ini, formula:

$$
\operatorname{Tobin}^{\prime} s Q=\frac{M V E+D E B T}{T A}
$$

Profitabilitas dalam penelitian ini diukur keseluruhan dengan ekuitas perusahaan. dengan Return on Assets (ROA). Rasio ini Berikut dijabarkan rumus untuk membandingkan antara jumlah utang meghitung ROA:

$$
\text { Return On Assets }=\frac{\text { Earning After Tax }}{\text { Total Assets }}
$$

Leverage diukur menggunakan Debt to dan Total Ekuitas. DER dapat diperoleh Equity Ratio (DER) dengan dengan formula berikut:

membandingkan antara Total Liabilitas

$$
\text { Debt to Equity Ratio }=\frac{\text { Total Liabilities }}{\text { Total Equity }}
$$

Ada sekitar 91 indeks yang ada di dalam CSRDI (Corporate social responsibility Disclosure Index) dengan ketentuan bahwa angka 1 akan diberikan jika item CSR diungkapkan dan angka 0 akan diberikan jika item CSR tidak diungkapkan oleh perusahaan. Berikut dijabarkan formula perhitungan CSR berdasarkan penelitian (Dewi, Trisna, \& Ni Gst., 2018):

$$
\operatorname{CSRDI}_{j}=\frac{\sum X_{i j}}{n j}
$$


Keterangan :

CSRDIj : CSR Disclosure Index

perusahaan

$\mathrm{Nj} \quad$ : Banyaknya item dalam

perusahaan, $\mathrm{nj} \leq 91$

Penelitian ini dilakukan dengan menggunakan bantuan software

Econometric Views versi 9.0. Di mana dengan bantuan software ini, dapat dilakukan beberapa pengujian yaitu seperti Uji Statistik Deskriptif, Uji Model Common

\section{HASIL DAN PEMBAHASAN}

Hasil dan pembahasan pada penelitian ini yaitu nilai perusahaan (firm value) yang diukur menggunakan Tobin's $Q$ memiliki nilai rata-rata (mean) sebesar 1.630922 dengan standar deviasi yang merupakan nilai variasi data dari perusahaan manufaktur adalah sebesar 1.290887. Nilai standar deviasi yang dimiliki oleh nilai perusahaan diketahui lebih kecil jika dibandingkan dengan nilai mean, pernyataan tersebut memiliki arti bahwa nilai perusahaan memiliki persebaran dan kesenjangan yang rendah dikarenakan skala standar deviasi yang lebih kecil dari nilai rata-rata. Nilai perusahaan memiliki nilai maximum sebesar 7.778480 di mana nilai ini di miliki oleh Semen Baturaja (Persero) Tbk di $\sum \mathrm{X}_{\mathrm{ij}} \quad$ : Nilai 1 diberikan jika item diungkapkan. Nilai 0 diberikan jika item tidak diungkapkan.

Effect, Uji Model Fixed Effect, Uji Model Random Effect, Uji Likelihood/Chow dan Hausman, dan juga uji asumsi data seperti Uji Koefisien Determinasi (R2). Uji F Statistik ANOVA, dan juga Uji t Partial.

tahun 2017. Sedangkan nilai minimum dari nilai perusahaan adalah sebesar 0.304140 yang dimiliki oleh Intanwijaya Internasional Tbk pada tahun 2016.

Profitabilitas menunjukkan nilai ratarata (mean) sebesar 0.089271, dengan standar deviasi yang merupakan nilai variasi data dari perusahaan manufaktur adalah sebesar 0.128225. Profitabilitas memiliki persebaran dan kesenjangan yang tinggi dikarenakan hasil standar deviasi lebih tinggi dibanding nilai ratarata. Profitabilitas memiliki nilai maximum sebesar 0.967500 dan nilai ini dimiliki oleh Star Petrochem Tbk pada tahun 2017. Sedangkan nilai minimum dari Profitabilitas memiliki nilai sebesar 0.001210 yang terdapat di Nusantara Inti 
Corpora Tbk pada tahun 2018.

Leverage memperlihatkan hasil nilai mean sebesar 0.743349 dan nilai median adalah 0.548885 . Leverage memiliki standar deviasi senilai 0.687920 yang artinya leverage memiliki persebaran dan kesenjangan yang rendah dikarenakan hasil standar deviasi yang lebih kecil daripada nilai rata-rata. Nilai maximum yang dimiliki Leverage sebesar 4.189710. Nilai tersebut terdapat di Indal Aluminium Industry Tbk tahun 2016. Sedangkan nilai minimum dari Leverage adalah sebesar 0.083300 yang dimiliki oleh Industri Jamu dan Farmasi Sido Muncul Tbk pada tahun 2016. Dilihat dari nilai antara standar deviasi dan nilai rata-rata.

Nilai rata-rata (mean) yang dimiliki CSR adalah 0.228205 dan nilai tengah (median) yaitu 0.219780 dengan standar deviasi senilai 0.091467. CSR memiliki persebaran dan kesenjangan yang rendah dikarenakan standar deviasi yang lebih kecil daripada nilai rata-rata. CSR memiliki nilai maximum sebesar 0.560440 yang terdapat pada JAPFA Comfeed Indonesia Tbk di tahun 2018. Sedangkan nilai minimum yaitu 0.076920 yang terdapat pada Sepatu Bata Tbk di tahun 2016.

Sebelum dilakukan perumusan terhadap hipotesis, pertama-tama akan dilakukan suatu pengujian terhadap Moderated Regression Analysis (MRA) atau Analisis Regresi Moderasi. Penelitian ini juga melakukan beberapa proses pengujian lainnya seperti Uji Common Effect, Fixed Effectl, Random Effectl, Uji Chow dan Hausman, Uji F dan Uji t serta Uji Koefisien Determinasi. Berikut adalah beberapa pengujian yang dilakukan dalam penelitian ini:

\section{Uji Common Effect Model}

\begin{tabular}{|c|c|c|c|c|}
\hline \multicolumn{5}{|c|}{ Dependent Variable: Y } \\
\hline \multicolumn{5}{|c|}{$\begin{array}{l}\text { Method: Panel Least Squares } \\
\text { Date: } 04 / 04 / 20 \text { Time: } 21: 21\end{array}$} \\
\hline \multicolumn{5}{|l|}{ Sample: 20162018} \\
\hline \multicolumn{5}{|l|}{ Periods included: 3} \\
\hline \multicolumn{5}{|c|}{ Cross-sections included: 50} \\
\hline \multicolumn{5}{|c|}{ Total panel (balanced) observations: 150} \\
\hline Variable & Coefficient & Std. Error & t-Statistic & Prob. \\
\hline $\mathrm{C}$ & -0.250679 & 0.454721 & -0.551280 & 0.5823 \\
\hline PROFITABLITAS & 3.643475 & 2.510653 & 1.451206 & 0.1489 \\
\hline LEVERAGE & 0.678987 & 0.392064 & 1.731830 & 0.0854 \\
\hline CSR & 8.968115 & 1.951525 & 4.595440 & 0.0000 \\
\hline ROAXCSR & -9.080017 & 10.28194 & -0.883103 & 0.3787 \\
\hline$\underline{\text { DERXCSR }}$ & -4.729836 & 1.848093 & -2.559307 & 0.0115 \\
\hline
\end{tabular}




\section{Uji Fixed Effect Model}

Dependent Variable: $Y$

Method: Panel Least Squares

Date: 04/04/20 Time: 21:26

Sample: 20162018

Periods included: 3

Cross-sections included: 50

Total panel (balanced) observations: 150

\begin{tabular}{crrrc}
\hline Variable & Coefficient & Std. Error & t-Statistic & Prob. \\
\hline C & 3.290658 & 0.751014 & 4.381620 & 0.0000 \\
PROFITABLITAS & -2.799130 & 1.462641 & -1.913750 & 0.0587 \\
LEVERAGE & -0.675490 & 0.545301 & -1.238748 & 0.2185 \\
CSR & -4.779317 & 3.245833 & -1.472447 & 0.1442 \\
ROAXCSR & 8.458068 & 5.538616 & 1.527108 & 0.1301 \\
DERXCSR & 0.041863 & 2.313158 & 0.018098 & 0.9856 \\
\hline
\end{tabular}

\section{Uji Random Effect Model}

Dependent Variable: Y

Method: Panel EGLS (Cross-section random effects)

Date: $04 / 04 / 20$ Time: $21: 56$

Sample: 20162018

Periods included: 3

Cross-sections included: 50

Total panel (balanced) observations: 150

Swamy and Arora estimator of component variances

\begin{tabular}{crrrr} 
Variable & Coefficient & Std. Error & t-Statistic & Prob. \\
\hline C & 1.327226 & 0.502913 & 2.639076 & 0.0092 \\
PROFITABILITAS & -2.103980 & 1.401532 & -1.501201 & 0.1355 \\
LEVERAGE & 0.079639 & 0.405242 & 0.196522 & 0.8445 \\
CSR & 3.325886 & 2.096451 & 1.586436 & 0.1148 \\
ROAXCSR & 6.725149 & 5.343722 & 1.258514 & 0.2102 \\
DERXCSR & -2.736471 & 1.837710 & -1.489065 & 0.1387 \\
\hline
\end{tabular}

\section{Uii Chow}

Redundant Fixed Effects Tests

Equation: Untitled

Test cross-section fixed effects

\begin{tabular}{lrrr}
\hline \hline Effects Test & Statistic & d.f. & Prob. \\
\hline \hline Cross-section F & 16.836776 & $(49,95)$ & 0.0000 \\
Cross-section Chi-square & 340.574845 & 49 & 0.0000 \\
\hline
\end{tabular}


Berdasarkan tabel, diperoleh nilai prob pada cross-section chi-square yaitu sebesar 0.0000 dan disimpulkan bahwa $\mathrm{H}_{0}$ ditolak dan $\mathrm{H}_{1}$ diterima sehingga model estimasi data panel yang paling tepat dan terbaik digunakan untuk penelitian ini adalah Fixed Effect Model.

\section{Uji Hausman}

Correlated Random Effects - Hausman Test

Equation: Untitled

Test cross-section random effects

\begin{tabular}{llcc}
\hline Test Summary & $\begin{array}{l}\text { Chi-Sq. } \\
\text { Statistic }\end{array}$ & Chi-Sq. d.f. & Prob. \\
\hline \hline Cross-section random & 18.300639 & 5 & 0.0026 \\
\hline
\end{tabular}

Diperoleh nilai probabilitas dari crosssection random yaitu sebesar 0.0026 , dapat disimpulkan bahwa $\mathrm{H} 0$ ditolak dan $\mathrm{H} 1$ diterima dan model estimasi data panel yang paling tepat dan terbaik dipilih untuk penelitian ini adalah Fixed Effect Model.

\section{Uji Analisis Regresi Moderasi}

Berdasarkan hasil uji, maka didapatkan seperti di bawah ini:

persamaan regresi yang dirumuskan

$$
\mathrm{FV}=3.290658-2.799130 \mathrm{X}_{1}-0.675490 \mathrm{X} 2-4.779317 \mathrm{X} 3+8.458068 * \mathrm{X}_{3}+0.041863 * \mathrm{X}_{3}+\varepsilon
$$

Hasil perolehan tersebut menunjukkan nilai dari koefisien regresi variabel profitabilitas adalah negatif sebesar 2.799130 yang memperlihatkan jika terdapat penambahan pada profitabilitas sebesar satu satuan dan nilai perusahaan yang menurun sebanyak 2.799130. Nilai perolehan koefisien regresi dari variabel leverage adalah sebesar negatif 0.675490 yang menunjukkan bahwa leverage mengalami suatu penambahan atau peningkatan sebesar satu satuan dan nilai dari perusahaan akan menurun sebesar
0.675490. Nilai perolehan koefisien regresi dari variabel Corporate Social Responsibility (CSR) adalah sebesar negatif 4.779317. Hal tersebut berarti jika variabel Corporate Social Responsibility $(C S R)$ naik sebesar satu dan nilai dari perusahaan akan menurun sebesar 4.779317. Nilai koefisien regresi dari ROA*CSR adalah sebesar positif 8.458068. Nilai tersebut berarti bahwa ROA*CSR mengalami peningkatan sebesar satu satuan dan disimpulkan bahwa nilai dari perusahaan akan 
mengalami kenaikan sebesar 8.458068. Nilai koefisien regresi dari DER*CSR adalah sebesar positif 0.041863. Nilai tersebut berarti bahwa DER*CSR mengalami peningkatan sebesar satu satuan dan disimpulkan bahwa nilai dari perusahaan akan mengalami kenaikan sebesar 0.04186 .

\section{Uji Statistik F}

\section{Prob(F-statistic)}

Berdasarkan dari hasil tabel pengujian di atas, ditunjukkan bahwa nilai dari Prob atau probabilitas (F-Statistic) adalah sebesar $0.000000<0.05$, dan dapat

\section{Uji Koefisien Determinasi (R2)}

\begin{tabular}{ll}
\hline Adjusted R-squared & 0.869399 \\
\hline
\end{tabular}

Nilai perolehan dari koefisien determinasi

atau Adjusted R-square adalah 0.869399

atau $86.94 \%$ yang menunjukkan bahwa

sebesar $86.94 \%$ merupakan kemampuan dari variabel independen profitabilitas, leverage dan juga variabel moderasi CSR dalam hal menjelaskan variasi dari variabel dependen nilai perusahaan.

\section{Uji t}

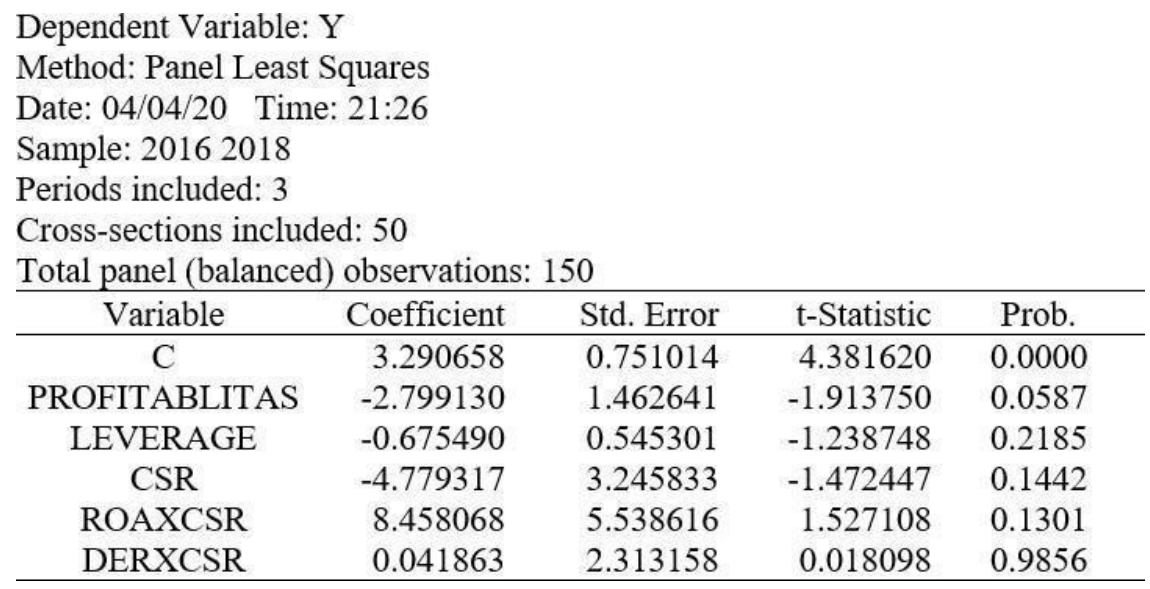


Berdasarkan hasil pengujian parsial yang telah dilakukan, diketahui bahwa Profitabilitas menunjukkan pengaruh yang negatif dan tidak signifikan pada nilai perusahan, leverage menunjukkan pengaruh negatif dan tidak signifikan pada nilai perusahaan, hasil pengujian juga menunjukkan bahwa Corporate Social Responsibility (CSR) memiliki

\section{SIMPULAN}

Berdasarkan hasil dan kesimpulan dari penelitian yang telah diperoleh, dapat ditarik kesimpulan bahwa terdapat beberapa keterbatasan di antaranya adalah (1.) Penelitian ini hanya menggunakan dua variabel independen dan satu variabel moderasi saja di antara sekian banyak variabel yang dapat mempengaruhi nilai perusahaan, (2.) Penelitian ini hanya fokus mengamati perusahaan manufaktur yang terdaftar di Bursa Efek Indonesia saja, (3.) Penelitian ini hanya mencakup periode tiga tahun saja dan perusahaan yang dijadikan sampel penelitian

\section{DAFTAR PUSTAKA}

Berthelot, \& Robert. (2011). Climate Change Disclosures: An Examination of Canadian Oil and Gas Firms. . Issues In Social And Environmental Accounting, 5th Edition (2), , 106. doi:https://doi.org/10.22164/isea.v5i 2.61 pengaruh negatif tidak signifikan pada nilai perusahaan. Hasil pengujian menunjukkan Corporate Social Responsibility (CSR) memperlemah pengaruh Profitabilitas pada nilai perusahaan dan Corporate Social Responsibility (CSR) memperlemah pengaruh Leverage pada nilai perusahaan.

hanyasebanyak 50 (lima puluh) perusahaan saja. Sehingga data penelitian ini kemungkinan tidak merefleksikan keadaan perusahaan yang sebenarnya. Berdasarkan batasan yang sudah diuraikan, maka saran yang dapat diberikan adalah dengan dilakukan penambahan jumlah variabel independen yang dapat mempengaruhi nilai perusahaan, dapat dilakukan penambahan jumlah sampel perusahaan yang diteliti dan perluasan tahun penelitian dan dapat dilakukan juga perubahan sektor lain yang tidak hanya mencakup manufaktur saja.

Deegan, C. M. (2014). Financial Accounting Theory 4E. In North Ryde N.S.W. Australia: McGraw-Hill Education.

Dewi, A., Trisna, W., \& Ni Gst., P. W. (2018). Pengaruh Profitabilitas pada Nilai Perusahaan dengan Corporate Social Responsibility Sebagai 
Variabel Intervening. E-Jurnal Akuntansi Universitas Udayana 22 (2), 1557-1583.

Fahmi, I. (2015). Pengantar Manajemen Keuangan Teori dan Soal Jawab. Bandung: Alfabeta.

Hadi, N. (2014). Corporate Social Responsibility. Yogyakarta: Graha Ilmu.
Kasmir. (2014). Analisis Laporan Keuangan. Depok: Raja Grafindo Persada. Scott, W. R. (2015). Financial Accounting Theory 7th Edition In Financial Accounting Theory. US: McGraw Hill Education.

www.idx.co.id

https://www.sahamok.com 